\title{
Editorial: Subaqueous Volcanism, From Ancient Successions to Modern Volcanoes and Modelling
}

\author{
Carles Soriano ${ }^{1 *}$, Nancy Riggs ${ }^{2 *}$ and Guido Giordano ${ }^{3 *}$ \\ ${ }^{1}$ Instituto de Ciencias de la Tierra Jaume Almera, CSIC, Barcelona, Spain, ${ }^{2}$ Merriam-Powell Center for Environmental \\ Research, Northern Arizona University, Flagstaff, AZ, United States, ${ }^{3}$ Department of Science, Roma Tre University, Rome, Italy
}

Keywords: processes, products, underwater eruptions, underwater vehicles, bathymetry

\section{Editorial on the Research Topic}

\section{Subaqueous Volcanism, From Ancient Successions to Modern Volcanoes and Modelling}

Understanding the processes and products of subaqueous volcanism has been traditionally based on the study of ancient successions and deposits; only a few studies are based on deposits from recent subaqueous eruptions and fewer yet on the direct observation of underwater eruptions. This situation has rapidly changed during last decades of the twentieth century and first decades of the twenty-first century, during which scientific and technological development has allowed an

OPEN ACCESS

Edited and reviewed by: Valerio Acocella,

Roma Tre University, Italy

${ }^{*}$ Correspondence:

Carles Soriano

csoriano@ictja.csic.es

Nancy Riggs

nancy.riggs@nau.edu

Guido Giordano

guido.giordano@uniroma3.it

Specialty section:

This article was submitted to

Volcanology,

a section of the journal

Frontiers in Earth Science

Received: 15 January 2020

Accepted: 04 February 2020

Published: 21 February 2020

Citation:

Soriano C, Riggs N and Giordano G (2020) Editorial: Subaqueous

Volcanism, From Ancient Successions to Modern Volcanoes and Modelling.

Front. Earth Sci. 8:42.

doi: 10.3389/feart.2020.00042 increasing exploration of the sea floor. Understanding of subaqueous volcanism has benefited from such exploration and from an increasing number of studies on modern volcanoes under the sea. As a result, the processes and products of subaqueous eruptions are now much better understood than ever before. Nevertheless, the study of ancient volcanic successions around the world still is a major source of models for subaqueous eruptions and, together with experimental and numerical modeling, is a major contribution to our understanding.

The present Research Topic showcases current trends in research on subaqueous volcanism, with a dominance of oceanographic surveys aimed toward the study of modern volcanoes and their deposits by using a number of techniques such as different types of underwater vehicles (AUVs, ROVs) and of high-resolution sonar bathymetries.

Cas and Simmons is a review with a summary of the physical properties of water and on how these may affect magma properties and eruptive processes like magma decompression, volatile exsolution and, ultimately, volcanic explosiveness. This contribution discusses a major issue in subaqueous volcanism that has driven a long-standing controversy: the hydrostatic pressure exerted by water column and its capability to inhibit explosive eruptions. It also addresses a process that has been increasingly investigated in both subaerial and subaqueous volcanic studies, as is the non-explosive production of ash by pumice-to-pumice abrasion.

The Havre volcano in the Kermadec arc erupted in 2012 and is likely one of the best-documented recent deep-water eruptions on Earth. Two contributions in the Research Topic are devoted to the study of this eruption of silicic magma. Ikegami et al. focuses on the chronostratigraphic relations of lavas and domes to reconstruct the chronologic history of the Havre eruption based on vent distribution and on lava and dome stratigraphy. They also provide a critical comparison of the Havre lavas and domes with subaerial counterparts, finding close similarities between them.

Murch et al. analyzed the Ash with Lapilli unit from Havre volcano by means of ROV sampling and detailed imagery. They use their results to highlight the important role that small-volume ash beds play in understanding subaqueous volcanic activity as a whole. 
Clague et al. report on the construction and destruction processes in a volcanic seamount to the southeast of Hawaii Island. Construction events were followed by vertical collapses due to lateral migration of basaltic magma to feed flank rift eruptions, yielding morphology of nested calderas, pit craters, and resurgent caldera blocks. Down-talus emplacement of basaltic pillows during eruption and syn-eruptive landslides on volcano flanks modified volcanic edifices.

Chadwick et al. present documentation of the first known historical eruption in the Mariana spreading center in December 2015 , with a depth of $>4,000 \mathrm{~m}$ below sea level. Multiple surveys, both from ships and using submersible ROVs, let the authors pinpoint the timing of eruption within a 3-year period. Although the Mariana system has a slow spreading rate, the study concludes that an active magmatic system is clearly present.

Cavallaro and Coltelli investigates the morphology of the Graham Volcanic Field (Sicily Channel, Italy) based on HighResolution Seafloor Mapping and ROV Images. Their results show the tectonic control on the N-S and NW-SE alignment of monogenetic cones, which include the remnant of the 1,831 submarine-to-emergent eruption that formed the now totally dismantled Ferdinandea Island.

Rizzo et al. analyzed the geochemistry of $\mathrm{CO}_{2}$-rich gases associated with the Kolumbo submarine volcano, which lies next to Santorini (Hellenic Volcanic Arc, Greece). Their results show that magmatic gases equilibrate within the Kolumbo hydrothermal system at about $270^{\circ} \mathrm{C}$ and at a depth of $\sim 1 \mathrm{~km}$ b.s.l.
Goto and Tomiya's contribution discusses a Quaternary subaerial cryptodome, highlighting commonalities and differences with respect to domes that grow in underwater settings.

These contributions have improved our empirical and theoretical understanding of the processes and products of subaqueous volcanism. As scientific and technological development proceeds, more studies of modern sea-floor volcanoes will provide empirical data on which refinement of theoretical models will be based. This assures that our understanding of subaqueous volcanism will continue to improve.

\section{AUTHOR CONTRIBUTIONS}

All authors listed have made a substantial, direct and intellectual contribution to the work, and approved it for publication.

Conflict of Interest: The authors declare that the research was conducted in the absence of any commercial or financial relationships that could be construed as a potential conflict of interest.

Copyright (c) 2020 Soriano, Riggs and Giordano. This is an open-access article distributed under the terms of the Creative Commons Attribution License (CC BY). The use, distribution or reproduction in other forums is permitted, provided the original author(s) and the copyright owner(s) are credited and that the original publication in this journal is cited, in accordance with accepted academic practice. No use, distribution or reproduction is permitted which does not comply with these terms. 